\title{
A (Bio) Socio-Ecosystemic Response to the Problem of Learner Attrition: A Case for Ubuntu
}

\author{
Vussy Nkonyane \\ Department of Teacher Education, School of Education \\ University of South Africa \\ nkonyva@unisa.ac.za
}

Charlene DuToit

School for Teacher Continuing Education, Faculty of Education Sciences North-West University in Potchefstroom

Charlene.dutoit@nwu.ac.za

\section{Doi:10.5901/mjss.2014.v5n20p1636}

\begin{abstract}
Learner attrition is one of the major problems working against democratic South Africa in its attempt to redress the legacy of apartheid in the educational front in its different forms, namely: poverty, unemployment, illiteracy, and disease. Recent studies have been conducted on the phenomenon pertaining to the problem of learner attrition. The purpose of this article is to explore through a socio-ecological approach an effective and sustainable response to the problem of learner attrition. Structured interviews were used to collect data. Only four themes of those that emerged from the findings are used: teenage pregnancy; looking after siblings; lack of motivation; and poverty. The strength of this study lies in its recommendations, which we feel are not only academic ideas, but through the theory of Ubuntu talk directly to and with the realities and peculiarities of the South African education system and its society.
\end{abstract}

Keywords: learner attrition, interviews, socio-ecological, Ubuntu

\section{Introductory Background}

This study emanates from the recommendations of a previous study conducted by Mahlomaholo, Mamiala and Nkonyane (2010), entitled: (Attrition and African Learner Underrepresentation in the Grade 12 Top 20 List of the North West Education Department). The study focused on the observation of the Executive Authority in the North West Province that form a cohort of 53000 learners who started schooling in the same year, only $40 \%$ of these learners sat for their Grade 12 exams twelve years later. Such a high rate of attrition is not acceptable to the province and the country in terms of the current huge national and provincial investment(s) in human capital development (North West Education Department (NWED), 2008). Over 25\% of the Gross Domestic Product (GDP) is already being spent on education with the aim of enabling all learners to succeed so as to become productive citizens who will create jobs and provide the much needed high level and scarce skills (Mahlomaholo, Mamiala and Nkonyane 2010).

This particular paper explores ways and means of addressing the causes of learner attrition as represented by the four identified themes: teenage pregnancy; looking after siblings; lack of motivation; and poverty through a (bio) socioecosystemic approach as an effective and sustainable response to the situation. This is achieved by focusing more on the recommendations of the study by Mahlomaholo et al. (2010). Secondly, a literature review on learner attrition is done to critically analyze the causes of the problem. Furthermore, Bronfenbrenner's (1986) socio-ecosystemic theory is foregrounded for conducting this phenomenon. Lastly, a positive-interpretivist paradigm is applied for data collection, analyses and interpretations.

\section{Conceptualization of "Learner Attrition"}

The problem of learner attrition is not unique to South Africa and not surprisingly, the attributes thereof seem to be common throughout the world even though they vary in their degree of influence on the same phenomenon from place to place (Wikan, 2009); Rumberger and Lim (2008); Masitsa (2006); and Tella and Tella (2003). A critical challenge 
confronting educational researchers and practitioners in South Africa and other developing economies is how to deal decisively with poor academic performance and learner attrition in schools.

Internationally, there are various understandings of what school dropout is. According to the report of the Ministerial Committee on Learner Retention in the South African Schooling System (2007), in the USA, there are specific official qualifying criteria for an individual learner to be considered as a school dropout (NCES, 2002:1) and these are that: the learner was enrolled in school at some time during the previous school year; the learner was not enrolled at the beginning of the current school year; and the learner had not graduated from high school or completed a state-approved educational programme.

Furthermore, the learner is regarded as a school dropout if s/he does not meet any of the following exclusionary conditions for consideration (NCES, 2002): transfer to another public school district, private school, or state or districtapproved educational programme (including correctional or health facility programmes); temporary absence due to suspension or school-excused illness; or death. This includes learner absence due to pre-natal care during pregnancy and post-natal care of a child.

Even though the above NCES definitions are commonly agreed upon and used by researchers in the USA, there are researchers who embellish this interpretation, for instance; Daniel, Walsh, Goldstone, Arnold, and Reboussin (2006) who propose that individuals can be classified as not completing school when they have dropped out or taken a path that has led to them not successfully graduating from school with the associated qualifications. These researchers suggest that this includes youth who have decided to receive vocational training rather than finish secondary school. While this is largely consistent with the NCES definition, they differ in including the vocational training aspect. Dropping out has also been seen with "excessive absences", defined as more than 15, 20 or 30 days of unexcused absence. Barnet, Arroyo, Devoe and Duggan (2004, p.264) delineated drop out using two approaches: A) a learner can be classified as a drop out if his or her school records document has been withdrawn. B) If a learner was present at school in a given academic year fewer than 20 days of the 180 day American school year (i.e. unexcused absence for more than $88 \%$ of the school year), he or she was classified as dropped out.

A study from the Netherlands reveals that, similar to the definition proposed by the USA/NCES, school dropouts can also be considered as those who leave school without a basic qualification, that is, without the minimum level of education required for entering the job market (Luyten, Bosker, Dekkers \& Derks, 2003). In other words, those who leave school before the age of 16 , which marks the end of compulsory fulltime schooling, may be considered by the system in the Netherlands dropout.

\section{An Afrocentric Perspective on Learner Attrition}

In the South African context, school reform legislations and research on education access hold the same views on notions of drop out. In her study: An Investigation into the Social Experiences of Dropouts following their Reenrolment in Secondary Schools in Stutterheim District: Implications for School Leadership (2009), Jakuka gives an African understanding of the same concept by referring to the South African Schools Act of 1996 (SASA, 1996) that it regards a learner who has not completed secondary school, or the nine years of compulsory education, a dropout (SASA, 1996). But Brown (2009) cites the fact that since secondary schooling after grade 9 is not compulsory in South Africa, but optional, it is not entirely accurate to regard post-grade 9 learners who quit school as dropouts. He argues that the use of the word "stop-outs" is more accurate because those learners are free to stop attending school whenever they wish. The argument is that those learners should not be labelled dropouts when they have the option to leave after grade 9. In some education systems in the World, the entire period from primary to the end of secondary school (or grade 12) is compulsory. Using this perspective, Wayman (2001) defines drop out as a learner in grade R to 12 who had not attended school for at least 32 or 30 days, not transferred to another school nor is being home-schooled, and had not contacted the school system about readmission. Wayman's definition is in line with the one proposed by Morrow (1996:3-4) whose definition of drop out calls for a period of unexcused absence from school of two weeks or more. Although it could be argued that the period suggested by both of these authors is debatable, the authors nevertheless are very clear about the out-of-school duration which qualifies one as a dropout. Jakuja (2009) therefore generally understands school dropout as involving an action in which a person, for instance, leaves, or becomes detached from the system. It is a selective process of detachment, which sometimes is made involuntarily. In the school context, dropout commonly refers to the learner leaving school before the official exit grade level (Motala et al, 2007).

This paper subscribes to UNESCO's definition of dropout rate per grade as the percentage of pupils who drop out from a given grade in a given school year is adopted. It is the difference between $100 \%$ and the sum of the promotion and repetition rates (UNESCO, 2007: 347). 


\section{Synthesis of the Research Components of our Article}

Research Design: This paper is focused on describing the relationship between the four factors towards learner attrition described as themes in Mahlomaholo et al.'s (2010) study, and relate that with the recommendations that particularly place the parents at the centre of the solution of the problem. The question is: How can Ubuntu enhance the (bio) socioecosystemic approach in responding to the issue of learner attrition in South African context? To respond to this question, we collected and analyzed data using the quantitative descriptive paradigm even though the study itself is qualitative.

Sampling: We then decided on the nature and size of the sample to be included in the study. Our plan to select 80 schools, 20 coming from each of the four Districts for closer scrutiny and analysis did not materialise because of the failure of schools to provide us with information on learner enrolments. We then went to all the schools in the province (which were estimated to be 1763 at the time) to ask for particulars of learners from their schools who started Grade 1 in 1998 but left before completing Grade 12 in 2009. We were going to follow this cohort of learners that was supposed to have spent 12 years in the system. Unfortunately, this route also did not work well due to the 2010 FIFA World Cup and shorter academic year. Data from the schools were not coming as fast as we had expected.

Data collection and analysis: For data collection we constituted ourselves into a collective with a chairperson, two co-chairpersons, and a data collecting coordinator for each of the four Districts in the North West Province. Each pair of district coordinators (DC) was assisted by a data analyst in the data capturing, cleaning and analysis. Each of the two cochairs supervised, monitored and verified the data gathering, scoring, capturing and analyses processes taking place in the two pairs of Districts. Then the chairperson supervised and coordinated the activities at the highest level of the province.

Before we started with data collection, workshops were conducted on the acceptable research ethical standards we were to adhere to, like; ensuring confidentiality of all information we gathered, keeping the anonymity of participants intact, making sure that the participants are not harmed in any way, ensuring informed consent to participate with a guarantee that any one person could withdraw from the study any time he/she so wished or even refuse to provide information without any negative consequences.

We convened meetings of school principals with the support of the various Area Office managers and staff where we explained our intentions. It took about three months (from May to beginning of August) for the first set of data to come through. In the mean time (that is during the six weeks of the FIFA World Cup and school holidays) we went via the public media, local radio stations, some hospitals, taxi and bus ranks, large employers like Shoprite and prisons to attempt to get as much information as possible regarding the whereabouts of the 1998 to 2009 cohort of learners who left school early. However, little progress was made.

The breakthrough occurred ultimately when we went through the Communications Department of the NWED to send e-mails to all staff within the Public Service in the province. The Organiser of the Youth Commission then got hold of our flyers and posters wherein we were asking for the mentioned early school leavers to come forth and send us SMSs for us to call them back and interview them. The Youth Commissioner connected us directly to the Community Development Workers (CDW). These are people appointed by the government to facilitate service delivery in the various municipality wards in the province (and nationally). These are people who in their respective wards know almost all the needs of the people. They are the ones who serve the advocacy role of bringing the plight of say, the poor to the attention of the South African Social Security Services Agency (SASSA) for grants, and etcetera. They collect data about every facet of the lives of the people in their wards, and know them intimately. We worked with these people from the end of August until the end of the data gathering section of the project on November 30, 2010.

We asked for permission to meet with the early school leavers (ESLS) in their respective wards through the local municipality coordinators with the help of the CDWs by making appointments through the CDWs and municipality coordinators. During our visits to various wards in different local municipalities with the CDWs, municipality officials accompanied us with loud hailers to invite the early school leavers from their homes to community halls appointed with the help of the CDWs for our meetings and interviews. The CDWs introduced us and explained the purpose of our visit. The CDW as the contact person knew the communities and many of the individuals therein and as such it was strategic to have him/her to lead the process of interacting with the learners in their communities. We supported the CDW and explained the difficult parts further, like what we were going to do with the data.

In actual fact the early school leavers from whom we gathered information cannot be described as the sample since they are not representative of the population in the true quantitative sense of the word, but rather they are valuable in their own individual right as dynamic and unique participants capable of interpreting and making sense of the world (Mahlomaholo \& Nkoane, 2002).

Frequency tables are used to represent data from the structured interview questionnaires, but, the study is 
qualitative, meaning that we use numbers merely to describe broad patterns and not to determine causality, to generalise, to predict and/or formulate general laws about attrition under all circumstances.

Summary and Total of All Early School Leavers (EsI) by Gender and Age Versus Employment Status in the North West Province as a Whole

\begin{tabular}{|c|c|c|c|c|c|c|c|c|c|c|c|c|c|c|c|c|c|c|c|c|c|}
\hline \multirow[b]{3}{*}{ Age Group } & \multicolumn{6}{|c|}{ At Home Unemployed } & \multicolumn{6}{|c|}{ Employed Elsewhere } & \multicolumn{6}{|c|}{ Another School/Abet/Prison/etc. } & \multicolumn{3}{|c|}{ Totals } \\
\hline & \multicolumn{3}{|c|}{ Female } & \multicolumn{3}{|c|}{ Male } & \multicolumn{3}{|c|}{ Female } & \multicolumn{3}{|c|}{ Male } & \multicolumn{3}{|c|}{ Female } & \multicolumn{3}{|c|}{ Male } & & & \\
\hline & $>17$ & 17 & $<17$ & $>17$ & 17 & $<17$ & $>17$ & 17 & $<17$ & $>17$ & 17 & $<17$ & $>17$ & 17 & $<17$ & $>17$ & 17 & $<17$ & & & \\
\hline \multicolumn{22}{|l|}{ Reasons LSE } \\
\hline 1.Failure & 58 & 135 & 1251 & 67 & 109 & 1064 & 65 & 23 & 96 & 19 & 5 & 37 & 42 & 12 & 23 & 80 & 17 & 35 & 1705 & 1433 & 3138 \\
\hline 2.Long distances & 13 & 36 & 226 & 25 & 19 & 113 & 15 & 11 & 26 & 0 & 0 & 4 & 6 & 7 & 13 & 0 & 0 & 0 & 353 & 161 & 514 \\
\hline 3.Pregnancy & 22 & 43 & 641 & 0 & 0 & 0 & 111 & 4 & 128 & 0 & 0 & 0 & 6 & 0 & 6 & 0 & 0 & 0 & 961 & 0 & 961 \\
\hline 4.Poverty & 80 & 88 & 1039 & 92 & 76 & 799 & 197 & 122 & 313 & 15 & 1 & 27 & 7 & 6 & 13 & 0 & 0 & 1 & 1865 & 1011 & 2876 \\
\hline 5.III-health & 7 & 11 & 118 & 8 & 7 & 71 & 24 & 2 & 25 & 0 & 0 & 3 & 2 & 2 & 4 & 0 & 0 & 1 & 195 & 90 & 285 \\
\hline 6. Attraction of odd jobs & 14 & 22 & 128 & 4 & 13 & 157 & 9 & 6 & 46 & 3 & 7 & 38 & 0 & 0 & 7 & 8 & 1 & 9 & 232 & 240 & 472 \\
\hline 7.Looking after siblings & 1 & 5 & 15 & 0 & 2 & 14 & 3 & 0 & 3 & 0 & 0 & 0 & 0 & 0 & 0 & 0 & 0 & 0 & 27 & 16 & 43 \\
\hline 8.Lack of motivation & 133 & 90 & 786 & 116 & 95 & 696 & 35 & 37 & 79 & 13 & 11 & 47 & 4 & 3 & 11 & 59 & 7 & 12 & 1178 & 1056 & 2234 \\
\hline 9. Early marriage & 1 & 3 & 23 & 2 & 90 & 3 & 2 & 0 & 2 & 0 & 0 & 0 & 0 & 0 & 0 & 0 & 1 & 10 & 31 & 106 & 137 \\
\hline 10. Transfer & 93 & 61 & 194 & 49 & 33 & 194 & 440 & 30 & 136 & 511 & 36 & 201 & 197 & 217 & 1036 & 168 & 217 & 1078 & 2404 & 2487 & 4891 \\
\hline 11. Criminal activity & 0 & 0 & 2 & 5 & 4 & 10 & 0 & 4 & 4 & 0 & 0 & 0 & 0 & 0 & 2 & 0 & 0 & 7 & 12 & 26 & 38 \\
\hline 12. Removal/resettlements & 21 & 6 & 48 & 12 & 2 & 15 & 0 & 0 & 0 & 0 & 0 & 0 & 0 & 0 & 0 & 0 & 0 & 0 & 75 & 29 & 104 \\
\hline 13. Abuse at school/home & 0 & 0 & 2 & 0 & 0 & 0 & 0 & 0 & 0 & 0 & 0 & 0 & 0 & 0 & 0 & 0 & 0 & 0 & 2 & 0 & 2 \\
\hline Totals & 443 & 500 & 4473 & 380 & 450 & 3161 & 901 & 239 & 858 & 561 & 60 & 357 & 264 & 247 & 1115 & 315 & 243 & 1153 & 9040 & 6680 & 15695 \\
\hline
\end{tabular}

Only four themes have been selected for the purposes of this paper as indicated earlier. Together these themes point to the present social dilemma of the disintegration of the family as known in the African philosophy of Ubuntu.

\subsection{Teenage pregnancy (Pregnancy)}

Some girls due to high levels of poverty ill advisedly decide to get pregnant for purposes of securing social grants only to discover that this is at even a greater cost to their future and the future of their children as they have to leave school and try to raise the baby with even more limited financial means. This problem is rife and it disadvantages girl-children even more, especially under these extreme conditions of marginalization.

\subsection{Poverty, financial problems, poor families and support (Poverty)}

Many learners the world over, leave school early (see discussion in chapter 2) because of poverty. Some do not have basic amenities like food, clothing, means of travelling to school, boarding and lodging fees and so on. They come from homes and families where nobody works or where the few that work do not get enough income to sustain their education as well. Such families are not able to provide support to their children due to financial constraints. Some of these families are headed by the children themselves due to the ill-health and/or passing on of the parent. These learners cited instances of cold families, where there is no caring, where abuse including incest is the order of the day. This category refers to parents who instead of providing a place of safety, security and love actually making it impossible for their offspring to continue with any education at school.

\subsection{Looking after siblings (Looking after siblings)}

Many families due to ill health-related to their socio-economic status are left to the care of the children who have to stop attending school. Some children have to sacrifice schooling to look after their siblings and /or ailing parents

\subsection{Lack of motivation, negligence, delinquency, bullying and truancy (Lack of motivation)}

Some learners became discouraged to continue with schooling because of a myriad of reasons including truancy. They skipped school maybe due to peer pressure or just the pleasure of being with friends. Some learners could not stay focused on their learning, they lost motivation, and they neglected their studies and their responsibilities generally. Others were victims of bullying at school and they left because of fear while others were perpetrators and this led them to being 
expelled from school.

\section{Discussion}

Ubuntu: I am because we are and because we are, you are.

I am because we are and because we are, you are. This straightforward proclamation encapsulates a philosophical understanding of interconnectedness and intercommittedness between individuals inside a community (Du Toit \& Nkonyane, 2011:3). The meaning of the above proclamation of 'I am' and 'you are', refers to the person and the 'we are' refers to the community we are living in. The meaning of the exceeding is that the individual understands that she/he derives her/his uniqueness from being in a commune. This bond between individuals inside a specific community provides the sanctuary, shelter and refuge that allow persons and in particular learners (children) to develop and grow further than plain endurance needs.

Inside this attachment of a joint community, the collective experiences of individuals outline the foundation on which a society is built. Membership in this specific community where one takes a little from another and all, the parental as well as community involvement and support has a significant effect on students' academic aspirations. The implication of the above is that everyone is since they all are joined inside a communal. Through membership and sharing within this communal, people expand empathy and sympathy with one another. Inside this community, individuals are bound by their norms, values and traditions, and the society promotes the development of the character and personality of individual's (learner's) distinctiveness. The affiliation among the individuals and the social order/commune, consequently, is based on mutual value. In the family unit, inside the communal component, the bonding is between parents and children. Children develop in the community in which they are nurtured and belong to. The purpose of a community is where individual learners get in touch with a wider commune/society where they need to have a chance to develop a more multipart individuality and a better sense of dependability. It is thus also the responsibility of the community to make sure that learners develop into responsible and accountable human beings (Du Toit, 2011).

The community gives the individual learner thus a social uniqueness. Without the communities support and guidance, the individual learner would have no openness, interconnectedness, empathy, sympathy, understanding, support, guidance, direction, assistance, and would not develop an understanding of what it means to be human. Also, the community must endeavour a cohesive and indispensable sense/need to belong and to be part of a meticulous community in a constantly deepening, heartfelt, communally commonly cohesive and equally trusting foundation of magnetism. In this community, learners should experience an extraordinarily profound and interhuman niveau that he/she belongs to a particular community which must be seen as a communal society. Within this communal society, learners must experience that they belong to that particular community and where there is the prospect for intercommitment, interdependence, mutual development, trust, consistency and social integrity (Du Toit, 2011). Thus, inside such a community, where Ubuntu is the foundation, the community, the village should raise a child; the community must protect, love, and be the safety net of learners.

The learners are not merely a beneficiary of the socialisation process, but also take part in it and add to it. Each person plays an imperative function in developing the community as a social unit. Every deed, achievement of the individual, whether close relative or adolescent, adds to the structure of the community and helps to establish its path. If there is mutual respect, care, support, understanding interdependence, to name a few, it will function for the advantage of all members in the community; therefore, I am because we are and because we are, you are (Du Toit, 2011). As the family unit is the fundamental building block of the social order, the community depends on the healthy performance of the family, and more specifically, the wellbeing of the learner/child inside such a family. Communality, the expansion of the family unit, provides the learner with numerous extra opportunities to cultivate, mature and develop.

Thus, as seen throughout this article, an understanding of the interdependence connecting the individual, the learner, and the social order -the community, leads to an understanding of one's dependability, accountability and responsibility to oneself and to the community. As a community/commune nurtures the individual, it is thus to the benefit and improvement of the individual to add commitment to it. In doing this, her/his greatest role to construct a sympathetic, kind-hearted community, the individual is doing the best for her/himself (Du Toit, 2011). For that reason, Ubuntu is the spirit of democracy in a democratic system. The old African adage says: "it takes the whole village to raise a child". As if this was not enough, the African people continued to say, "Any child is my child". The above assertion forms part of the core principles of the African philosophy Ubuntu as indicated earlier on in the paper. Wisdom should have informed these so called "barbaric" people that the biological parent is not self-sufficient (time will come where biological parent will not be self-sufficient) to support the child to grow into a fully responsible citizen. There are other factors beyond the confines 
of the home that still bear a lot of influence on how and what self-identity the child comes to develop. Bringing up a child therefore becomes the responsibility of the whole community. This attitude is critical today where the basic unit of society (family) is not as strong as it was before; single family units, child-headed families, unemployed parents, sickly parents, and etcetera. It is not uncommon to read or hear of a child who cannot go to school because s/he is taking care of a sick mother or father. This may be civilized but un-African. This argument is also supported by Mahlomaholo, et al. (2010) who state that the disadvantaged, lower class, unstable and unattractive background groups are the most devastated by attrition.

Any intervention strategy should therefore seriously take into consideration the practical realities of the context to successfully address learner attrition problem in South Africa. On the basis of a critical analysis of family presently and consideration of the crisis inherent therein, the following recommendations are made. On the basis of our observation of contemporary communities, these recommendations are not applicable to suburban South Africa, but are aimed at the township, informal settlement, and rural communities with the intention of exploiting the community itself as a source and resource in helping learners affected by these conditions to avoid poor performance hence escape leaving school earlier.

\section{A (Bio) Socio-Ecosystemic Response}

This concept is taken from Bronfenbrenner's ecological model which recognises the importance of individual and contextual factors on learner functioning as well as the reciprocal nature of interactions between individuals and their contexts over time (Bronfenbrener, 1986). As a framework, it extends prior theoretical contributions by incorporating numerous influences in multiple ecological contexts recognising that learning and development are influenced not only by individual propensities but also by the interpersonal relationships and social environments within which they develop. Parents, peers, and teachers are important social figures in students' multiple worlds; supportive and positive relationships with important figures optimise students' motivation to be actively engaged in learning and stay longer at school (Brown, Mounts, Lamborn, \& Steinberg, 1993).

Bronfenbrenner's $(1986,2001,2004,2005)$ ecological model is painted with the biological concept so that we can be able to talk about how learner attrition is deconstructed and constructed at the following eco-systemic levels: (i) the micro, where each individual learner interacts with his or her family/school/peers, (ii) the meso level where these social groupings including the individual African learner interact among themselves, (iii) the exo level where these interacting social groupings constitute neighbourhoods and /or communities, (iv) the macro where all the above social groupings individually and interacting in neighbourhoods constitute social structures, ideological blocks and so on and finally (vi) the chrono level where all the above operate in the context of development in (historical) time. Biologically, the cell is selfsufficient and sustainable. An attempt is made in this paper to adopt the functional operations of a cell into human socioecosystemic functions.

\subsection{Formation of community cells (CCs)}

Parents need to be grouped into small units according to their streets or neighbourhood. These units are called Community Cells. Parents are responsible to look after the welfare of the learners in that particular cell; whether learners are going to school daily, studying and doing homework, have food, are not being abused; respect their parents, and other things that they may identify as important for the children. It may happen that among the parents in a cell some are educated and can assist their children with homework. Such parents then become a resource for the whole cell. They should organize a central place where it will be easy for the learners in the cell to meet after school for two or three hours a day and do their work under the supervision of the parent(s). And in case there are many such parents, some should be allocated to cells that do not have such manpower. The high illiteracy rate among parents should not be seen as a problem, but an opportunity to empower them with good parenting skills as demanded by our present situation. They can be used in making constant visits to the child-headed families in the cell. This assists in the earlier identification of problems that the learners may be facing like shortage of food, clothes, study material, or delinquency on the part of the learners. It is better to deal with such problems earlier on and nip them in the bud than dealing with the ill-consequences thereof. It is noted that the parents in a cell may not have solutions for all the problems (opportunities) they encounter. There are NGO's and people with relevant skills for particular cases. The parents should work closely with the schools in a cell and report that to teachers. Teachers will then talk to the relevant stakeholders to solve the problem. Cell members work together on a daily basis and look into challenges and how they can address them. It is also wished that each cell has a teacher. 


\subsection{Formation of Community Tissues (CTs)}

In a neighbourhood, different cells should group together and form a tissue. The duty of a tissue is to monitor the smooth functioning of all cells under it. Each CT must have at least one police officer to whom they can report all law related issues in their place. The police are not there just to arrest criminals, but as a brother, sister or parent who gives well informed advice, love and care. This kind of relationship between the police and learners can help solve drug abuse and prevent a lot of other criminal activities that have beset our communities. What our learners need mostly today are good role models. The CT can also be allocated a social worker who will have the records of all children in the particular CT and is readily available for counselling and assistance when need arises. Most of the learners discussed herein do not have official documents to access government grants. It is hoped that a pastor will be available for spiritual purposes. The church has a critical role to play in the challenges that face South African society. It is not by fault or coincidence that the struggle for liberation was led by church man. The different cells in a tissue meet regularly to exchange views and share experiences towards addressing challenges and the development of their area.

\subsection{Formation of Community Organs (COs)}

Different CTs group together and form Community Organ (CO). Each CO should have at least one local role model; it can be a school principal, an education departmental official, a nurse, the mayor, the municipal manager, or a successful local business person. The role of this person is to inspire the children to commit to schooling. One role model can belong to different $\mathrm{Cos}$ because s/he does not attend to the $\mathrm{CO}$ on a daily basis. The role model advises learners on careers and other profession-related issues can also assist with information on bursaries and asking for funds from the private sector for needy children in the CO.

Lack of parental involvement has always been pointed at as the major source of all educational problems for learners by research. The trick here is how to coerce or make parents attend to school meetings and get them involved in their children's school work. "If the mountain cannot go to Mohammed, then Mohammed must go to the mountain". Under this arrangement it is easy to access parents through one of the social structures as explained above. This allows teachers to go to either structure of community convenient to them and interact with parents. Training in parenting skills can also be done wherever there is a need.

All social organs should be represented in this system at all levels wherever possible. The local government structures should form the core of this strategy. The CDWs through their wealth of experience are very critical in taking this endeavour forward. In a CO there will be a teacher who is an expert in maths, physics, and etcetera and such teachers become assets to all the CTs in that area. An overemphasis is on sharing of resources for the benefit of all. Effectively employed, the above theory does not only take care of educational needs of learners, but a host of other social ills as well including the rampant juvenile crime rate in our country, substance abuse by youth, street children, spread of HIVIAIDS.

\section{Conclusion}

Research by Aremu, Tella and Tella (2003) points out that parental involvement and academic achievement are positively related. Findings have demonstrated that parents' involvement in the education of the children have benefits to parents, children and the schools (Tella \& Tella, 2003; Campbell, 1995; Rich, 1987). Another study by Rasinki and Fredericks (1998) also concluded that parents play an invaluable role in establishing the foundation for their children's learning. Zang and Carrasquillo (1995) also similarly remarked that when children are surrounded by caring, capable parents and are able to enjoy nurturing and moderate competitive kinship, a foundation for literacy is built with no difficulty.

Considerable evidence can be drawn from the above authors that a variety of different parenting practices and expectations directly contribute to students' academic achievement. Important parenting practices include parental participation in school activities, parental educational aspiration for their children, parent-child communication, and parental supervision, (Fan, 2001); Feuerstein, 2000). Some researchers suggest that parental involvement and support may influence students' school adjustment indirectly by influencing children's social, emotional, cognitive competence, and attitudes. Ross and Broh (2000) found that parental support facilitates adolescents' perceived control and selfesteem over time.

Similarly, Schickedanz (1995) also reported that children of passive parents were found to perform poorly academically. In addition, Murrel (2007) reported that academic performance is positively related to having parents who enforce rules at home. The obviousness of the research findings of this study is that family involvement improves learner 
achievement, hence prevents learners from dropping out from school. In the North West Province as in the whole of South Africa, the intersectionality of race, culture and social class distinctions still play a role in the development of partnerships between the home, school and community. Lower class and low income homes which are invariably African, do not command respect both in society and the school. To support the above, Murrel (2007: 5) argues that

Socio-economic status (SES) affects behaviour through its impact on an individual's aspirations, sense of efficacy, personal standards and emotional states. A strong sense of efficacy can help strengthen resiliency to adversity often found in the environment of the low SES student. Low SES learners often live in chaotic and unstructured environments. They live day to day. They may be unable to manage their emotions, have poor role models, and feel they have no choice or control over their destiny.

Murrel (2007) further suggests that learner achievement is an activity occurring within a community, and that school success is achievable for all learners when learning is understood as the acquisition of a set of preferred cultural practices and as we come to see teaching and learning as the socialization of these cultural practices in educational settings. This creates a sense of self-worth on the practitioners and owners of the cultural practices. Status based on socio-economic factors represents one of the major systems of stratification. The value of socio-economic factors for predicting academic achievement, hence leaving school early seems to be especially supported by research. White (1986) and Morakinyo (2003) indicate the existence of a relationship between socio-economic status and academic achievement. McGee (1996: 32) support Morakinyo (2003) in these words, that;

Families with high socio-economic status often have more success in preparing their young children for school because they typically have access to a wide range of facilities or goods providing their young children with high-quality child-care, books, and toys to encourage children in various learning activities at home, they also have easy access to information regarding their children's health, as well as social, emotional, and cognitive development.

For families in poverty conditions, the challenges towards providing optimal care and education for their children are formidable. Sometimes, when basic necessities are lacking, parents must place top priority on housing, food, clothing and health care. Educational toys, games, and books may appear to be luxuries, and parents may not have the time, energy or knowledge to find innovative and less expensive ways to foster their children's development. Families with low socio-economic status often lack the financial, social, and educational supports that characterize families with higher socio-economic status. Poor families may also have inadequate or limited access to community resources that promote and support children's development and school readiness. Poor parents may have inadequate skills for such activities as reading to and with their children, and they may lack information about childhood immunizations and nutrition. As a result, the risk for children from families with low socio-economic status to perform poorly at school is great.

One of the social issues facing 'children of poverty' is emotional trauma. The emotional climate can often be very stressful and emotionally depriving. The lack of emotional nurturing can lead to feelings of alienation, inadequacy, depression and anxiety hence problems of truancy, lack of motivation, delinquency, drug abuse, criminality, not being able to cope with the cognitive and emotional demands of schooling, academic failure thus being held back in one class for some years hence exceeding the age limit to remain at school or just being discouraged due to lack of progress and attendant poor performance. Learning is always a problem under such circumstances. Poverty can also make learners not to afford transport costs when schools and institutions of learning are a distance away from their home. Children of poverty may not even afford to pay for accommodation to stay closer to the schools they are attending. Unplanned teenage pregnancies become the order of the day when idle young people experiment with sex without proper guidance from parents and the able others.

Aggressive or impulsive behaviour and social withdrawal can also result. Emotional security and self-esteem are often lacking. There is a craving for attention and a need to belong (Ciaccio, 2000; Brophy, 2000). The characteristics that are lacking in the poverty environment are those that help foster effective learning and academic success. Emotional draining and negative self-status can literally zap the motivation to learn out of children. Children from poverty homes start out in life at a disadvantage. Their mothers may have no or inadequate pre-natal care. They may have insufficient early health care thus leading to proneness to diseases and illnesses. If the parents are fortunate to have jobs, affordable day care may be of poor quality (Slavin, 1998). Additionally, poor children do not have the same kind of experiences that children of other social classes do. The experiences they miss out on are those that could help in the development of skills and academic achievement. Some examples would be; the use of home computers; visits to zoos and museums; attendance at pre-school programs; availability of literature and educational reading materials; interaction with educated, literate and well-spoken adults; and being read to by a parent. The social environment that is present in conditions of poverty affects the development of these children by limiting the ways they learn to live in social groups. Opportunities for intellectual development, such as cognitive skills and thinking patterns, are the result of social interaction. Children who live in poverty conditions are unable to develop mutually satisfying social relationships. Language is an important tool in 
the process of learning to think. If children have limited opportunities to learn a language, organize perceptions, and develop other higher order cognitive processes, their ability to solve problems and think independently is negatively affected (Bowman, 1994; Guerra \& Schutz, 2001; Bandura, 2001).

The above argument is evidence enough to locate the solution of the problem at parents. And considering the harsh reality our communities are facing on the parent phenomenon, it is logical to conclude that the community in the form of cells, tissues and organs should be roped in to fill the gap of the parent in the child's life. In anyway, Ubuntu says; "Any child is my child", and "It takes the whole village to raise a child".

\section{References}

Aremu, A.O. (2000). Impact of home, school, and government on primary school pupils' academic performance. The Exceptional Child, 5, (1), 106- 110. Available at: http://www.pef.uni-lj.si/atee/978-961-6637-06-0/261-269.pdf.

Balfanz, R. AND Letgers, N. (2009). How many Central City High Schools have a severe dropout rate, where are they located, and who attend them? Paper presented at the ,Dropouts in America: How severe is the problem? What do we know about Intervention and Prevention?' A forum convened by the civil rights project. Cambridge. Massachusetts: Harvard University.

Bandura, A. (2001). Social cognitive theory: An agentic perspective. Annual Review of Psychology, WilsonWeb July 11, 2001.

Barnet, B., ARROYO, C., DEVOE, M. and DUGGAN, A.K. (2004). Reduced school

Bowman, B. (1994). The challenge of diversity. Phi Delta Kappan, vol. 76: 234- 38. WilsonWeb July 16, 2001.

Bronfebrenner, U AND Morris, P. A. (2006). The bioecological model of human development. In Damon, W. and Lener, R.M (Eds. In Chief) and Lener, R.M (Vol.Ed.),

Bronfenbrenner, U. (2001). The bio-ecological theory of human development. In Smelser, N.J \& Baltes, P.B (Eds.). International encyclopaedia of the social and behavioural sciences, Vol.10, 6963-6970. New York: Elsevier.

Bronfenbrenner, U. (2004). Making human beings human: Bioecological perspectives on human development. New York: Wiley.

Bronfenbrenner, U. (2005). Making human beings human: Bioecological perspectives on human development. Thousand Oaks: Sage Publications, Inc.

Brophy, J. E. (2000). Teacher-student relationship: Causes and consequences. New York: Holt Rinehart and Winston.

Brown, B. (2009). Social hostility and the drop out dilemma: Leadership assisting dropouts in schools? Education Review, 14(4): 187 205.

Campbell, DR. (1995). Racial residential segregation: A fundamental cause of racial disparities in health. Public Health reports, Viewpoint vol. 116: 404 - 416 care. Arch Paediatric Adolescent Medicine, 158, pp. 262-268.

Ciaccio, J. (2000). A teacher's chance for immortality. The Education Digest, vol. 65(6): 44- 8. WilsonWeb July 11, 2001.

Daniel, S.S., Walsh, A.K., Goldston, D.B., Arnold, E.M., Reboussin, B.A. and Wood, F.B. (2006). Suicidality, school dropout, and reading problems

Department OF Education (1996b). South African Schools Act 84. Pretoria: Government Gazette dropout rates among adolescent mothers receiving school-based prenatal

Du Toit, C. (2011). Riglyne vir effektiewe onderwys in afkampusonderwysprogramme vir praktiserende onderwys, Published PhD. Potchefstroom: NWU.

Du Toit, C. and Nkonyane, V.A. (2011). Distance education as a "we-ness": A case for Ubuntu as a theoretical framework.

Emis, North West Education Department Available at:http://www.nwpg.gov.za/education/ Accessed May 01, 2010 for School Leadership at the University of Fort Hare: South Africa.

Fine, M. (2001). Framing dropouts: Notes on the politics of an urban public high school. Albany NY: State University of New York Press.

Guerra, C. AND SCHUTZ, R. (2001). Vygotsky. Available at http://www.english.sk.com.br/sk-vygot.html Accessed on October 25, 2010.

Jakuja, D.P. 2009. An Investigation into the Social Experiences of Dropouts following their Unpublished Med Dissertation:

Levin, R. (1991). People's Education and negotiations. Perspectives in Education, vol. 12 (2): 33 - 48

Lin, N. (1999). Building a network theory of social capital. Connections, vol. 22 (1): 28 -51.

Loring, B. (2005). "Sir Cyril Burt: Scientific Fraud", In C. Loring Brace, Race is a Four Lettered Word, the Genesis of the Concept. Oxford University Press.

Luyten, H., Bosker, R., Dekkers, H. and Derks, A. (2003). Dropout in the lower

Mahlomaholo MG AND Nkoane MM (2002). The case for an emancipatory qualitative research. Reflections on Assessment of quality. Education as Change, vol. 6(1), pp. 69 -84.

Mahlomaholo, M. G.; Mamiala, T. \& Nkonyane, V. A. (2011). Attrition and African Learner Underrepresentation in the Grade 12 Top 20 List of the North West Education Department.

Masitsa, G. (2006). Drop-out in township secondary schools: educators' perspectives. Acta Academica, vol. 38 (3), 165 -191.

Mcgee,K. (1996). One family at a time. Educational Leadership, 53: 30-33. WilsonWeb July 10, 2011.

Ministerial Committee on Learner Retention in South African Schooling System, 2007. National Department of Education.

Morakinyo, A. (2003). Relative efficacy of systematic desensitization, self statement monitoring and flooding on subjects test anxiety. Unpublished PhD. Thesis. University of Ibadan.

Morrow, R. A. (1996). Critical theory and methodology. Thousand Oaks, CA: Sage.

Motala, S., Dieltiens, V., Carrim, N., Kgobe, P., Moyo, G. AND Rembe, S. (2007). Educational access in South Africa. Country Analytic 
Review. Johannesburg: Consortium for Research on Educational Access, Transitions and Equity. Wits University Education Policy Unit.

Murrel, P.C. (2007). Race, Culture, and Schooling: Identities of Achievement in Multicultural Urban Schools. New York: Routledge.

National Centre FOR Education Statistics. (2006) The Condition of Education. Published report. Washington: NCES.

North West Education Department (2008) Annual report 2007/2008. Mmabatho: pp.373-41. Vision Press, Published report. Washington: NCES.

Rasinki, TV., \& Fredericks, A. (1988). Sharing Literacy: Guiding principles and practices for parents' involvement. Reading Teachers, 41 508- 513.

Reenrolment in Secondary Schools in Stutterheim District: Implications

Rumberger, R. AND LIM S.A. (2008) Why learners drop out of school: A review of 25 years of research. California Drop out Research Project. University of California: Santa Barbara.

Schickedanz, JA. (1995). Family Socialization and Academic Achievement. Journal of Education, vol. 1: 17- 34.

Slavin, R. (1998). Can education reduce social inequality? Educational leadership, vol. 55: 6- 10. WilsonWeb July 18. 2001.

Tella, A. and Tella, A. (2003). Parental involvement, Home background, and School Environment as Determinant of Academic Achievement of Secondary School Students in Osun State, Nigeria. African Journal of Cross-Cultural Psychology and Sports Facilitation, 5, (2), 42-48. Tracks of Dutch secondary education: predictor variables and variation.

Unesco. (2007). Theories of Education Leadership and Management, 3rd edn.UK: Sage Publications.

Wayman, J.C. (2001). Factors Influencing GED and Diploma Attainment of High School Dropouts. Education Policy Analysis Archives. 9(4). Online: Available url: http://epaa.asu.edu/epaa/v9n4/. Accessed: November 2009.

White, T.A. (1986). Obstracism at work: The painful effect of the cold shoulder. Online: Available url: www.workplacebullying.suite101.com/article. Accessed: November 2008.

Wikan, G. (2009) Non-enrolled, drop-outs and pupils: The State of Education for All in Namibia. The 31st Annual Conference of Association of Teacher Education in Europe.

Zang, S.Y. AND CARRASQUILLO, A.L. (1995). Chinese Parents' Influence on Academic Performance. New York State Association for Bilingual Education Journal, 10, 46-53. 